\title{
Sunflower Genotype Selection for Oil Production in the Pre-Amazon Region of Brazil
}

\author{
Francirose Shigaki ${ }^{1}$, Ludhanna Marinho Veras ${ }^{2}$, Elane Tyara de Jesus Siqueira ${ }^{1}$, José Roberto Brito Freitas ${ }^{1}$, \\ Mayanna Karlla Lima Costa ${ }^{1}$, Cláudio Guilherme Portela de Carvalho ${ }^{3} \&$ Marcos Gervasio Pereira ${ }^{4}$ \\ ${ }^{1}$ Federal University of Maranhão, Chapadinha, Maranhão, Brazil \\ ${ }^{2}$ Faculty of Agrarian and Veterinary Sciences, Estadual Paulista University, Jaboticabal, São Paulo, Brazil \\ ${ }^{3}$ Brazilian Agricultural Research Corporation (Embrapa Soja), Londrina, Brazil \\ ${ }^{4}$ Federal Rural University of Rio de Janeiro, Seropédica, Brazil \\ Correspondence: Francirose Shigaki, Center for Agrarian and Environmental Sciences, Federal University of \\ Maranhão, Chapadinha, Maranhão 65500-000, Brazil. E-mail: francirose@yahoo.com.br
}

Received: March 27, 2019

Accepted: April 28, 2019 Online Published: June 15, 2019

doi:10.5539/jas.v11n8p248

URL: https://doi.org/10.5539/jas.v11n8p248

\begin{abstract}
Part of the energy consumed in the world comes from limited sources, which eventually are expected to be depleted. The search for alternative sources to meet energy needs is crucial. Biodiesel derived from vegetable oils and animal fats stands out as a biodegradable and renewable alternative source of energy. Sunflower is among the top four oil crops produced worldwide, and Brazil has a high production potential for this crop. This study aimed to identify the sunflower genotypes with the highest potential for biodiesel production in the Pre-amazon region of Brazil, where the advance of agricultural frontier represents an important role on biodiesel production. This study was conducted over 2 years of observations. The following genotypes were used: M734 (T), Helio358, EMBRAPA 122, and BRS G 35. The following parameters were assessed: initial flowering date (IFD), physiological maturity date (PMD), plant height (PH), grain yield (YIELD), thousand achene weight (TAW), and oil content (\%OC). The climatic conditions of each experimental period were distinctive and directly affected the results obtained. The genotype Embrapa 122 showed the best performance regarding yield and was recommended for the pre-Amazon region of Brazil as the best adapted genotype to the local environmental conditions.
\end{abstract}

Keywords: Helianthus annuus L., oil content. Biodiesel

\section{Introduction}

The search for viable alternative sources of energy has generated several research studies on oilseed crops for oil extraction for biodiesel production. Sunflower (Helianthus annuus L.) stands out among those crops, ranking fourth worldwide, behind soy, palm, and canola (United States, 2017).

Brazil has a high potential for biodiesel production from sunflower due to its geographical location, territorial extension, and favorable climate and soil conditions. Sunflower is a crop with key agronomic characteristics, such as drought tolerance, higher than that of most species commonly grown in Brazil, and its yield is mostly unaffected by latitude, altitude, and photoperiod (Souza et al., 2015). However, the sunflower acreage in Brazil remains low due to factors such as the lack of processing industries and studies on crop genotypes in different locations, which could increase productivity, especially in the Pre-amazon region of Brazil, where the advance of agricultural frontier represents an important role on biodiesel production.

The Brazilian Legal Amazon Region extends over an area of approximately 5,200,000 $\mathrm{km}^{2}$ and represents $59 \%$ of Brazil's land mass. Its population of twenty four million people are distributed over 775 municipalities and the region is home to a very high ecological and socio-economic diversity (Almeida et al., 2016). The agriculture studies in the Pre-Amazon region represent a important role, since results found can be expected to expand to other parts of Amazon, where it is important to maintain sustainability.

According to Arshad et al. (2013), in addition to increasing productivity, the use of best-adapted cultivars is a low-cost input in the production system and, therefore, easily adopted by farmers. Thus, new cultivars resulting from the identification of parameters of high yield and acceptable quality in different regions must be constantly 
assessed, while considering, in particular, the existence of genotype $\times$ environment interactions to determine the agronomic behavior of the genotypes and their adaptation to different local conditions (Casadebaig et al., 2011).

In the Legal Amazon region, Piauí and Maranhão states are the only states recommended by the Ministry of Agriculture, Livestock and Food Supply (Ministry of Agriculture, Livestock and Supply-MAPA-Brazil, 2016) for sunflower growth based on agricultural zoning (Embrapa Algodão, 2008). Genotypes that are able to meet all industrial demands regarding productivity and quality of the raw material must be identified. Accordingly, this study was conducted to identify the sunflower genotypes with the highest production potential for biodiesel production in the Legal Amazon Region of Brazil.

\section{Materials and Methods}

\subsection{Site Description}

The experiment was conducted at the Federal University of Maranhão (Universidade Federal do Maranhão-UFMA), at the Center of Agricultural and Environmental Sciences (Centro de Ciências Agrárias e

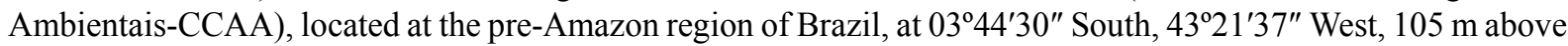
sea level (IBGE, 2015). According to the Köppen climate classification, this region has an Aw tropical climate with dry winter and rainy summer and $1400 \mathrm{~mm}$ average annual precipitation. The soil of the experimental area is classified as Oxisol (Latossolo Amarel) and has the following characteristics: $\mathrm{pH} 5.6$ in water, $0.65 \mathrm{cmol}_{\mathrm{c}} \mathrm{dm}^{-3} \mathrm{Ca}$, $0.25 \mathrm{cmol}_{\mathrm{c}} \mathrm{dm}^{-3} \mathrm{Mg}, 0.6 \mathrm{cmol}_{\mathrm{c}} \mathrm{dm}^{-3} \mathrm{Al}$, and $5.35 \mathrm{cmol}_{\mathrm{c}} \mathrm{dm}^{-3} \mathrm{H}+\mathrm{Al}$.

\subsection{Plant Material and Experimental Approach}

The genotypes M734 (control), Helio 358, Embrapa 122, and BRS G 35 were used. The first two genotypes are simple hybrids, and the last two are varieties (open-pollinated populations).

In the 1st study year, sowing was conducted on March 15, 2012. Sunflower germination occurred 3 days after planting. Two-stage fertilization (fertilization at planting and topdressing) was conducted. For the fertilization at planting, $60 \mathrm{~kg} \mathrm{~N} \mathrm{ha}^{-1}, 80 \mathrm{~kg} \mathrm{P}_{2} \mathrm{O}_{5} \mathrm{ha}^{-1}$, and $80 \mathrm{~kg} \mathrm{~K}_{2} \mathrm{O} \mathrm{ha}^{-1}$ were applied. Topdressing was performed 30 days after sowing, using $40 \mathrm{~kg} \mathrm{~N} \mathrm{ha}^{-1}$ and $50 \mathrm{~kg} \mathrm{~K}_{2} \mathrm{O} \mathrm{ha}^{-1}$, and leaf fertilization was performed 3 days after topdressing by applying Boron at a dose of $1 \mathrm{~kg} \mathrm{~B} \mathrm{ha}^{-1}$. Crop irrigation began 35 days after sowing, with the addition of an $8-\mathrm{mm}$ water blade, for 15 irrigations at $120 \mathrm{~mm}$.

Plants were measured 1 week before harvesting, which was 95 days after sowing. In the harvest, the two central rows were considered the useful area. Prior to harvest, the flower heads were covered with gunnysacks to protect them from birds. After the harvest, the samples were separated to analyze the production parameters. In the 2nd study year, sunflower sowing was performed on March 11,2013, with fertilization performed at planting and using the same nutrient doses as the 1st study year. Topdressing was performed on April 1, 2013, and Boron leaf fertilization was performed 10 days after topdressing.

The first irrigation was performed 34 days after sowing, using the same protocol as the first study year. However, because the 2 nd study year had a good precipitation index, supplemental irrigation was stopped 25 days after sowing to ensure good crop growth.

Harvesting was performed 102 days after sowing; then, the samples were separated and taken for analysis of production parameters.

\subsection{Experimental Design and Statistical Analysis}

A $4 \times 2$ factorial randomized block design was used with four sunflower genotypes and two periods (1st and 2nd year) in split-plots with four replicates, totaling 16 plots. Each plot had four 6-m-long rows separated by $0.70 \mathrm{~m}$, and each row had 21 plants spaced at $0.30 \mathrm{~m}$ apart. The data collected in the field and laboratory tests were subjected to analysis of variance and to the Tukey test at $5 \%$ probability. The data presented normality by the Shapiro Wilk test and homoskedasticity by the Cochran test. The yield (YIELD) variable showed normality but not homoscedasticity. Therefore, the values of this variable were Log2x-transformed (logarithm of $\times$ to the base 2 ) to assess the significance. The software used to perform the statistical tests was InfoStat $\AA$.

\subsection{Tests Performed}

Data were collected for the following assessments: initial flowering date (IFD), physiological maturity date (PMD), plant height (PH), grain yield (YIELD), oil content (\%OC), and thousand achene weight (TAW).

The method used to quantify the OC\% of the different genotypes was based on procedures defined by the International Union of Pure and Applied Chemistry (IUPAC), which have been revised and adapted by Embrapa Soja (2001). Extraction was performed with hexane followed by dichloromethane in a Soxhlet extractor with a 
500-mL distillation flask and a reflux condenser $25 \mathrm{~cm}$ in height by $5 \mathrm{~cm}$ in inner diameter. The process was repeated three times for each solvent, and the reflux was performed at intervals of approximately 10 min for 3 hours to estimate the yield of oil ha' ${ }^{-1}$.

\section{Results}

In the 1st year, the IFD ranged from 29 to 36 days, with M734 beginning to flower at 36 days, and the other genotypes beginning to flower at 29 days (Figure 1). Conversely, in the 2nd year, the genotypes M734, Helio 378, and Embrapa 122 began flowering at 60 days and the genotype BRS G 35 at 55 days. Significant differences $(\mathrm{P}<$ 0.05 ) in the PMD occurred between the genotypes tested only in the 1st study year, ranging from 58 to 65 days to reach physiological maturity; the genotypes BRS G 35 and Helio 378 required from 62 and 65 days, respectively, to reach maturity, whereas the other genotypes required 58 days (Table 1).

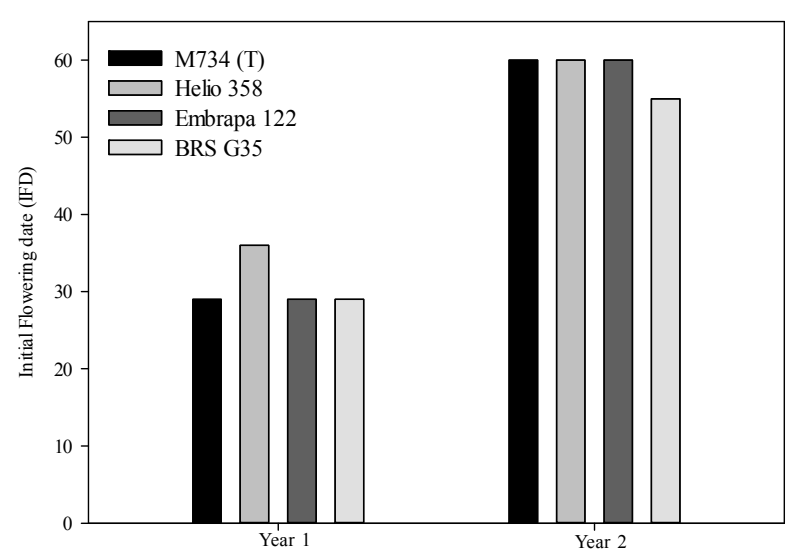

Figure 1. Initial flowering date (IFD) of four sunflower genotypes (Helianthus annuus L.) tested in two consecutive years

In the $2^{\text {nd }}$ year, physiological maturity ranged from 90 to 95 days, which was a later maturity but with no significant differences from the $1^{\text {st }}$ year. $\mathrm{PH}$ ranged from 70 to $87 \mathrm{~cm}$ in the $1^{\text {st }}$ study year, whereas $\mathrm{PH}$ ranged from 105 to $122 \mathrm{~cm}$ in the $2^{\text {nd }}$ year. However, no significant differences existed according to the Tukey test (p > 0.05). The parameter YIELD ranged from 1063 to $2531 \mathrm{~kg} \mathrm{ha}^{-1}$ among the genotypes in the $1^{\text {st }}$ year, and the genotype M734 (T) had the lowest value; in the $2^{\text {nd }}$ year, the genotype Embrapa $122(\mathrm{~T})$ stood out with a $2354 \mathrm{~kg}$ $\mathrm{ha}^{-1}$ yield, differing significantly from the other genotypes (Table 1).

No significant differences in the TAW were found between the genotypes in the $1^{\text {st }}$ study year, which ranged from 21 to $23 \mathrm{~g}$, and the genotypes in the $2^{\text {nd }}$ study year, which ranged from $21.7 \mathrm{~g}$ to $23.5 \mathrm{~g}$. Lastly, the genotype M734 (T) had the highest $\% \mathrm{OC}$ in the $1^{\text {st }}$ year, at $42 \%$, differing significantly $(\mathrm{P}<0.05)$ from the other genotypes, which showed no significant differences among each other. In the $2^{\text {nd }}$ year, no significant differences were found $(\mathrm{P}<0.05)$, with values ranging from 39 to $44 \%$, and the genotypes Helio 358 and BRS G 35 showed the best performances (Table 1).

In the $1^{\text {st }}$ study year, the OC\% was proportional to the YIELD for all genotypes, and the genotype M734(T) had the lowest ratio due to the YIELD of this genotype.

In the $2^{\text {nd }}$ study year, the Oil yield $\times$ yield ratio was similar to that of the $1^{\text {st }}$ year for all genotypes. However, the ratio of the genotype BRS G 35 was favorable in the $2^{\text {nd }}$ year, with a good oil yield, despite the lower YIELD than that in the $1^{\text {st }}$ study year (Figure 2 ). 
Table 1. Physiological maturity date (PMD), plant height (PH), grain yield (YIELD), oil content (\%OC), and thousand achene weight (TAW) of four sunflower genotypes (Helianthus annuus L.) tested in two consecutive years

\begin{tabular}{|c|c|c|c|c|}
\hline Genotypes & M734 (T) & Helio358 (T) & Embrapa $122(\mathrm{~T})$ & BRS G 35 \\
\hline Period & \multicolumn{4}{|c|}{ Physiological maturity date (PMD) } \\
\hline Year 1 & $58.0 \mathrm{Bb}$ & $65.0 \mathrm{Ab}$ & $58.0 \mathrm{Bb}$ & $62.0 \mathrm{ABb}$ \\
\hline Year 2 & $95.0 \mathrm{Aa}$ & $95.0 \mathrm{Aa}$ & $95.0 \mathrm{Aa}$ & $90.0 \mathrm{Aa}$ \\
\hline \multicolumn{5}{|c|}{ Plant height (PH) } \\
\hline Year 1 & $70.75 \mathrm{Ab}$ & $69.90 \mathrm{Ab}$ & $87.5 \mathrm{Ab}$ & $70.5 \mathrm{Ab}$ \\
\hline Year 2 & $114.0 \mathrm{Aa}$ & $113.0 \mathrm{Aa}$ & $122.75 \mathrm{Aa}$ & $105.0 \mathrm{Aa}$ \\
\hline \multicolumn{5}{|c|}{ Grain yield $\left(\mathrm{kg} \mathrm{ha}^{-1}\right)$} \\
\hline Year 1 & $227.84 \mathrm{Bb}$ & $520.56 \mathrm{Aa}$ & $542.52 \mathrm{Aa}$ & 509.78Aa \\
\hline Year 2 & $517.91 \mathrm{Ba}$ & $485.91 \mathrm{Bb}$ & $588.63 \mathrm{Aa}$ & $469.83 \mathrm{Bb}$ \\
\hline \multicolumn{5}{|c|}{ Thousand achene weight (TAW) } \\
\hline Year 1 & 23.0 & 21.0 & 21.0 & 24.0 \\
\hline Year 2 & 22.75 & 21.75 & 23.5 & 23.5 \\
\hline \multicolumn{5}{|c|}{ Oil content (OC\%) } \\
\hline Year 1 & 42.31 Aa & $36.40 \mathrm{Bb}$ & $35.56 \mathrm{Ba}$ & $35.32 \mathrm{Bb}$ \\
\hline Year 2 & $39.63 \mathrm{Aa}$ & $44.42 \mathrm{Aa}$ & $40.02 \mathrm{Aa}$ & $41.90 \mathrm{Aa}$ \\
\hline
\end{tabular}

Note. Means followed by the same letter-uppercase between genotypes and lowercase between years show no significant difference from each other, according to the Tukey Test $(\mathrm{P}>0.05)$.

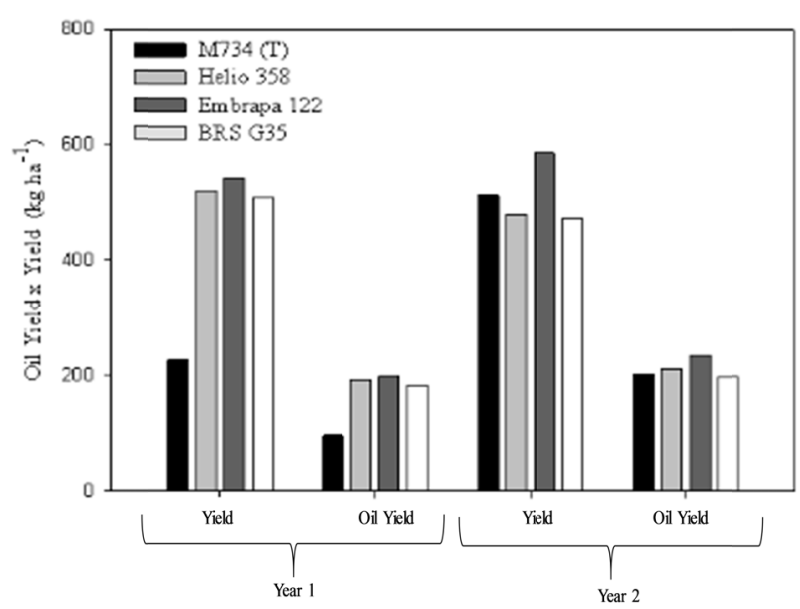

Figure 2. Oil Yield $\times$ Yield of four sunflower genotypes (Helianthus annuus $\mathrm{L}$.) tested in two consecutive years

\section{Discussion}

\subsection{Climatic Conditions}

Water stress is considered one of the most important limiting factors of plant performance and yield for sunflower crops worldwide (Asbagh et al., 2013). According to Tshwenyane (2014), sunflower requires a temperature range of 20 to $26^{\circ} \mathrm{C}$ and minimum rainfall of $500 \mathrm{~mm}$ during the crop cycle. During the experimental period of the 1st year, the average air temperature data ranged from 24 to $28{ }^{\circ} \mathrm{C}$, and the total rainfall was $460 \mathrm{~mm}$ (Figure 3), requiring the use of irrigation, which was performed every other day with an 8-mm water blade, thereby adding $120 \mathrm{~mm}$ water to the experiment by irrigation. Adding the volume of water provided to the experiment by irrigation $(120 \mathrm{~mm})$ to the volume of water provided by natural rainfall events $(460 \mathrm{~mm}), 580 \mathrm{~mm}$ was provided to the experiment, thereby meeting the water requirements of the crop, as previously mentioned. Conversely, in the experimental period of the $2 \mathrm{nd}$ year, the average air temperature ranged from 23 to $26^{\circ} \mathrm{C}$, and the total rainfall was $731.63 \mathrm{~mm}$ (Figure 3), with no supplemental irrigation required until the end of the experiment. 


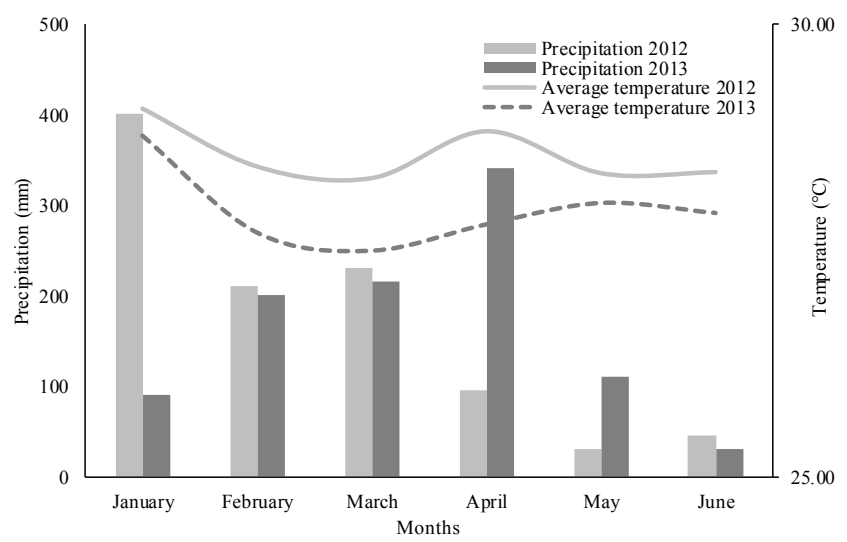

Figure 3. Rainfall assessed in Chapadinha, Maranhão (MA), from January to June in 2012 and 2013 (National Institute of Meteorology-INMET), 2015

\subsection{Initial Flowering Date (IFD)}

The IFD ranged from 29 to 36 days in the 1 st year and from 55 to 60 days in the 2 nd year (Figure 1). These significant differences between the phenological cycles of sunflower genotypes have already been observed in other studies (Khoufi et al., 2013; Godinho et al., 2011), both in Brazil and in other countries. They mainly resulted from changes in plant structure occurring because each part of the plant has a different water requirement, and different physiological processes were prevalent at the various stages of plant development. Furthermore, some plant structures are more sensitive than others to the decreased water potential of the soil and, therefore, decreased water in the plant tissues (Grieu et al., 2008).

In the 1st year, the genotype Helio 358 took 36 days to begin flowering, whereas the other genotypes used in the experiment-M 734 (T), Embrapa 122, and BRS G 35-began flowering at 29 days. In the 2nd year, the IFD of the genotypes M 734 (T), Helio 358, and Embrapa 122 occurred at 60 days, whereas the genotype BRS G 35 took 55 days to begin flowering. In the study conducted by Nobre et al. (2012), the agronomic characteristics of the 10 sunflower genotypes were assessed, including Helio 358 and M734 (T). The authors observed that the IFD of these genotypes ranged from 50 to 63 days, and these values were similar to the values observed in the 2nd study year in the present study. In contrast, in a study conducted by Migon et al. (2012), the genotypes Helio 358 showed late development, with an IFD ranging from 70 to 77 days.

Several studies have shown the effect of climatic conditions on the agronomic characteristics of sunflower genotypes (Pereyra-Irujo, 2009; Pekcan et al., 2015; Robert, Rajasekar, \& Manivannan, 2016). The beginning of the flowering period mainly depends on the genotype, temperature, and water availability (Kaleem, Hassan, \& Saleem, 2009; Garcia Lopez et al., 2014). The decreased total volume of water observed in the 1st study year may explain the early IFD in that year. In general, flowering was later for all genotypes assessed in the 2nd year, which may be explained by the different environmental conditions that prevailed during the period, including the increased total volume of water $(731.63 \mathrm{~mm})$ available to the crop. Furthermore, the high rainfall that occurred immediately after sowing in the 2nd year may have adversely affected early plant development.

\subsection{Physiological Maturity Date (PMD)}

The PMD variable showed significant differences $(\mathrm{P}<0.05)$ between the genotypes tested in the 1 st study year. When the volume of water available for proper crop development is limited, precocity is desirable to attenuate the environmental effect on grain filling, which enables a satisfactory YIELD (Nobre et al., 2012).

In the 1st year, the PMD ranged from 58 to 65 days, whereas the PMD ranged from 90 to 95 days in the 2 nd year. The latest PMDs assessed in the 1st year were found in the BRS G 35 and Helio 358 genotypes, which required 62 and 65 days, respectively, to reach physiological maturity. Conversely, the other genotypes tested in the 1 st year required 58 days to reach maturity. The differences in PMD among the genotypes may be correlated with receptacle size. According to Fernández-Luqueño et al. (2014) plants with small receptacles more easily lose water, thereby shortening the time to reach maturity.

In general, physiological maturity occurred later in the 2nd study year than in the 1st year for all genotypes, with no significant difference between them $(\mathrm{P}<0.05)$. According to Buriro et al. (2015), exposure to high temperatures, combined with water stress, may affect both water accumulation and loss from the fruit and stop grain growth, thus 
shortening the time to reach physiological maturity, which is longer in unstressed plants. Despite the use of complementary irrigation in the 1 st study year, a period of water stress may have occurred. This factor accelerated the senescence process, thereby accelerating leaf fall, stopping normal fruit growth and leading to an early PMD. According to Killi et al. (2017), the period of physiological maturity is characterized by water loss in the achenes. This period lasts from 20 to 30 days and is related to the rate of water loss, climatic conditions, and genotype.

\subsection{Plant Height (PH)}

The PH in the 1st study year ranged from 70 to $87 \mathrm{~cm}$, whereas PH ranged from 105 to $122 \mathrm{~cm}$ in the 2nd year. Like other variables of this study, the climatic conditions of each experimental period were decisive for the final values of $\mathrm{PH}$, with better results in all genotypes in the 2 nd study year, when the environmental conditions were favorable to plant development during most of the vegetative cycle, with an average increase of $40 \mathrm{~cm}$ in PH being observed for each genotype in the 2 nd year relative to the 1 st year. Within the 1 st and within the 2 nd study years, no significant difference $(\mathrm{P}>0.05)$ in $\mathrm{PH}$ values occurred among the sunflower genotypes.

In the study conducted by Pivetta et al. (2012), aimed at identifying superior sunflower genotypes, the authors observed that the $\mathrm{PH}$ was the only biometric parameter tested that showed significant differences between the study genotypes. Height is a key characteristic for mechanized agriculture, and it should be uniform to enable an adequate harvest without crop losses. Ivanoff et al. (2010) detected unevenness problems in the variables height, stem diameter, and flower head diameter in the variety Embrapa 122, and this unevenness may limit the use of mechanized harvesting. This unevenness was also found in Embrapa 122 and in BRS G35 in the present study because they are open-pollination populations.

Very tall sunflower plants may hinder plant pest control. However, the PHs (less than $1.3 \mathrm{~m}$ ) assessed for these genotypes do not preclude the application of pesticides and other plant pest-control measures. According to Carvalho, França Neto, and Krzyzanowsky (2006), tall plants are desirable, especially in environments with low disease control or low fertility levels.

\subsection{Grain Yield (YIELD)}

According to Lawal et al. (2011), YIELD is affected considerably by the flowering time of the crop because it affects the vegetative and reproductive growth. Except for genotype M734 (T), all genotypes showed high yield and grain performance in the 1st year, even though the plants were taller and had a longer cycle.

The genotypes M734 (T), Helio 358, Embrapa 122, and BRS G 35, in the 1st year, showed YIELD values ranging from 1063 to $2531 \mathrm{~kg} \mathrm{ha}^{-1}$. In studies conducted by De Oliveira et al. (2011) and Balbinot Junior, Backes and Souza (2009), values of $2000 \mathrm{~kg} \mathrm{ha}^{-1}$ and $1950 \mathrm{~kg} \mathrm{ha}^{-1}$ were found for the cultivars Helio358 and M743, respectively.

In the 1st year, the best YIELDs were found in Embrapa 122, BRS G 35, and Helio 358, and the genotype Embrapa 122 stood out in the $2 \mathrm{nd}$ year, with a yield of $2354 \mathrm{~kg} \mathrm{ha}^{-1}$, which differed significantly from that of the other genotypes. Thus, although Embrapa 12 is an open-pollination population, this was the only genotype that stood out in both study years. Compared with the use of hybrids, the advantage of using an open-pollination population is the lower seed price and the possibility of multiplication for own use.

\subsection{Thousand Achene Weight (TAW)}

The parameter TAW showed no significant difference among the genotypes in the 1st year, ranging from 21 to $23 \mathrm{~g}$, and the same performance and variation were observed in the 2nd experimental year, with weights ranging from 21.7 to $23.5 \mathrm{~g}$. In contrast to the findings of this study, differences in the TAW among the genotypes have been reported in other studies and are explained by the dry matter accumulation in the achenes, which depends on the genotype and the water availability (Canavar et al., 2010; Ion et al., 2015).

\subsection{Oil Content (OC\%)}

In the 1st experimental year, the sunflower genotype M734 (T) had the highest $\mathrm{OC} \%(\mathrm{P}<0.05)$, with $42 \%$. The other genotypes showed no significant differences among each other $(\mathrm{P}<0.05)$, with a mean value of $35 \%$. Conversely, in the 2 nd year, the values of the OC\% ranged from 39 to $44 \%$, albeit with no significant differences ( $\mathrm{P}$ $<0.05$ ) from each other. Agele et al. (2007) and Izquierdo et al. (2008) reported higher differences in oil OC\% among the sunflower genotypes than those found in the present study. Despite irrigating in the 1st study year, the crop may have experienced water stress in critical stages of growth, which did not favor the genotypes.

In the study by Andrianasolo et al. (2014), predicting the sunflower oil concentration as a function of the variety, crop management and environmental conditions, the authors concluded that the variety factor would rank first among oil concentration determinants. However, recent studies have shown different responses of sunflower 
genotypes regarding OC \% under different management and environmental conditions (Champolivier et al., 2011; Andrianasolo et al., 2012).

In addition to genotype and environmental conditions, the sunflower OC $\%$ may be affected by other factors, including the sowing time. Thomaz (2008) reported $34.7 \%$ to $42.6 \%$ OC\% in the genotype M 734 (T) sown at different times. These values are similar to the findings of the present study for the same genotype. However, in the present study, in both study years, sowing was performed at the same time, which should not affect the OC\% of the genotypes tested.

\subsection{Oil Yield $\times$ Yield Ratio}

In the study conducted by Backes et al. (2008), the genotype Embrapa 122 had the best YIELD. The same result was observed in both years of the present study, with the Embrapa 122 genotype showing good YIELDs and, therefore, the best Oil Yield $\times$ Yield ratio (Figure 2). According to Dalchiavon et al. (2016), the desirable OC\% for the industry is higher than $40 \%$; therefore, some companies provide bonuses to farmers who deliver achenes with values higher than $40 \%$ and penalize farmers when the values are lower than $40 \%$. The greater the bonus is for seeds with an OC $\%$ higher than $40 \%$, the greater the preference will be of farmers for hybrids with good oil yields as well as good YIELDs.

\section{Conclusion}

Considering the heterogeneity of the rainfall distribution as an important characteristic of the Pre-Amazon region of Brazil, the genotype Embrapa 122 is recommended to this region, showing high oil production under water stress conditions, which is common in this region.

\section{Acknowledgements}

The authors would like to thank FAPEMA — Fundação de Amparo à Pesquisa e ao Desenvolvimento Científico e Tecnológico do Maranhão ds/for funding this research.

\section{References}

Almeida, C. A., Coutinho, A. C., Esquerdo, J. C. D. M., Adami, M., Venturieri, A., Diniz, C. G., ... Gomes, A. R. (2016). High spatial resolution land use and land cover mapping of the Brazilian Legal Amazon in 2008 using Landsat-5/TM and MODIS data. Acta Amazonica, 46(3), 291-302. https://doi.org/10.1590/1809-4392 201505504

Andrianasolo, F. N. (2014). Prediction of sunflower grain oil concentration as a function of variety, crop management and environment using statistical models. European Journal of Agronomy, 54, 84-96. https://doi.org/10.1016/j.eja.2013.12.002

Andrianasolo, F. N., Champolivier, L., Maury, P., \& Debaeke, P., (2012). Plant density contribution to seed oil content the responses of contrasting sunflower genotypes grown in multi-environmental network. Proceedings of the 18th Inter. Sunflower Conf. (pp. 724-729).

Arshad, M., Khan, M. A., Ullah, I., \& Amjad, M. (2013). Development of short duration and high yielding indigenous sunflower (Helianthus annuus L.) hybrids. Sci. Tec. and Development, 32(3), 205-214.

Asbagh, F. T., Gorttapeh, A. H., Fayaz-Moghadam, A., Saber-Rezaie, M., Feghnabi, F., Eizadkhah, M., ... Moghadam-Pour, S. N. Effect of planting date and irrigation management on sunflower yield and yield components. Research Journal of Biological Sciences, 4, 306-308.

Backes, R. L., Sousa, A. M., Balbinot Junior. A. A., Galotti, J. M., \& Bavaresco, A. (2008) Desempenho de cultivares de girassol em duas épocas de plantio de safrinha no Planalto Norte Catarinense. Scientia Agraria, 9, 41-48. https://doi.org/10.5380/rsa.v9i1.10131

Balbinot Junior, A. A., Backes, R. L., \& Souza, A. M. (2009). Performance of sunflower cultivars in three planting dates in North plateau of Santa Catarina state. Scientia Agraria, 10-2. https://doi.org/10.5380/rsa.v10i2. 13581

Brasil, Ministério da Agricultura, Pecuária e Abastecimento. (2016). Retrieved from http://www.agricultura. gov.br

Buriro, M., Sanjrani, A. S., Chachar, Q. I., Chavar, N. A. Chachar, S. D., Buriro, B., ... Mangan, T. (2015). Effect of water stress on growth and yield of sunflower, Journal of Agricultural Science and Technology, 11, 1547-1563. 
Canavar, O., Ellmer, F., \& Chmielewski, F. M. (2010). Investigation of yield and yield components of sunflower (Helianthus annuus L.) cultivars in the ecological conditions of Berlin (Germany). Helia, 33, 117-130. https://doi.org/10.2298/HEL1053117C

Carvalho, M. L. M., França Neto, J. B., \& Krzyzanowsky, F. C. (2006). Controle e qualidade na produção de sementes. Informe Agropecuário., 27, 52-58.

Casadebaig, P., Guilioni, L., Lecoeur, J., Christopher, A., Champolivier, L., \& Debaeke, P. (2011). Sunflower, A model to simulate genotype-specific performance of the sunflower crop in contrasting environments. Agricultural and Forest Meteorology, 151, 163-178. https://doi.org/10.1016/j.agrformet.2010.09.012

Champolivier, L. (2011). Construire des stratégies de production adaptées aux débouchés à l'échelle du bassin de collecte. Innovations Agronomiques, 14, 39-57.

Dalchiavon, F. C., Carvalho, C. G. P., Amabile, R. F., Godinho, V. P. C., Ramos, M. P., \& Anselmo J. L. (2016). Características agronômicas e suas correlações em híbridos de girassol adaptados à segunda safra. Pesquisa Agropecuária Brasileira, 51, 1806-1812. https://doi.org/10.1590/s0100-204x2016001100002

EMBRAPA ALGODÃO. (2008). Oleaginosas e seus óleos: Vantagens e desvantagens para produção de biodiesel. Esberard de Macêdo Beltrão e Maria Isaura Pereira de Oliveira, Campina Grande.

Embrapa Soja (Empresa Brasileira de Pesquisa Agropecuária). (2001). Tecnologia para produção do óleo de soja: Descrição das etapas, equipamentos, produtos e subprodutos.

Fernández-Luqueño, F., Lopez Valdez, F., Miranda Aranbula, M., Rosas Morales, M., Pariona, N., \& Espinoza Zapata, R. (2014). An introduction to the sunflower crop (Chapter 1 in Sunflowers, pp. 1-18). Nova Science Publishers.

Godinho, V. P. C., Utumi, M. M., Carvalho, C. G. P., Brogin, R. L., Silva, G. S., Passos, A. M. A., \& Botelo, F. J. E. (2011). Avaliação de genótipos de girassol para o cerrado de Rondônia e Mato Grosso: Rede nacional (Final 2). Reunião Nacional de Pesquisa de Girassol (pp. 339-342).

Grieu, P., Maury, P., Debaeke, P., \& Sariffi, A. (2008). Améliorer la tolérance à la sécheresse du tournesol: Apports del'écophysiologie et de la génétique. Innovations Agronomiques, 2, 37-51.

IBGE (Instituto Brasileiro de Geografia e Estatística). (2012). Lavoura Temporária. Retrieved from http://www.ibge.gov.br/estadosat/temas.php?sigla=rn\&tema=lavouratemporaria2012

Ion, V., Dicu, G., Bassa, A. G., Dumbrava, M., Temocico, G., Epuri, L. I., \& State, D. (2015). Sunflower Yield and Yield Components under Different Sowing Conditions. Agriculture and Agricultural Science Procedia, 6, 44-51. https://doi.org/10.1016/j.aaspro.2015.08.036

Izquierdo, N. G., Dozio, G. A. A., Cantarero, M., Lujan, J., \& Aguirezabel, L. A. N. (2008). Weight per grain, oil concentration and solar radiation intercepted during grain filling in black hull and stripped hull sunflower hybrids. Crop Science, 48, 688-699. https://doi.org/10.2135/cropsci2007.06.0339

Ivanoff, M. E. A., Uchoa, S. C. P., Alves, J. M. A., Smirdele, O. J., \& Sediyama, T. (2010). Formas de aplicação de nitrogênio em três cultivares de girassol na savana de Roraima. Revista Ciência Agronômica, 41, $319-325$. https://doi.org/10.1590/S1806-66902010000300001

Kaleem, S., Hassan, F. U., \& Saleem, A. (2009). Influence of environmental variations on physiological attributes of sunflower. African Journal of Biotechnology, 8, 3531-9.

Killi, D., Bussotti, F., Raschi, A., \& Haworth, M. (2017). Adaptation to high temperature mitigates the impact of water deficit during combined heat and drought stress in C3 sunflower and C4 maize varieties with contrasting drought tolerance. Physiologia Plantarum, 159, 130-147. https://doi.org/10.1111/ppl.12490

Khoufi, S., Khamassi, K., Aoun, N., \& Jeddiet, R. S. F. (2013). Assessment of diversity of phenologically and morphologically related traits among adapted populations of sunflower (Helianthus annuus L.). Helia, 36, 29-40. https://doi.org/10.2298/HEL1358029K

Lawal, B. A., \& Mohmood, N. (2011). Effect of planting time on sunflower (Helianthus annuus L.) productivity in Ibadan, Nigeria. African Journal of Agricultural Research, 6, 3049-3054.

Migon, L. (2012). Avaliação do desempenho de híbridos de girassol na FAPAGRO Serra em Veranópolis/RS. Simpósio Estadual de Agroenergia, IV Reunião Técnica de Agroenergia-RS. 
Nobre, D. A. C., Resende, J. C. F., Junior, D. S. B., Costa, C. A., \& Morais, D. L. B. (2012). Desempenho agronômico de genótipos de girassol no norte de Minas Gerais, Rev.Agro@mbiente On-line, 6, 140-147. https://doi.org/10.18227/1982-8470ragro.v6i2.781

Pekcan, V., Evici, G., Yilmaz, M. I., Nalcaiyi, S. B., Erdal, S. C., Cicerik, N., Ekmecki, Y., \& Kaia, Y. (2015). Drought effects on yield traits of some sunflower inbred lines. Agriculture \& Forestry, 61(4), 101-107. https://doi.org/10.17707/AgricultForest.61.4.10

Pereyra-Irujo, G. A. (2009). Variability in sunflower oil quality for biodiesel production: A simulation study. Biomass and Bioenergy, 33, 459-468. https://doi.org/10.1016/j.biombioe.2008.07.007

Pivetta, L. G., Guimarães, V. F., Friorese, S. L., Pivetta, L. A., \& Castoldi, G. (2012). Avaliação de híbridos de girassol e relação entre parâmetros produtivos e qualitativos. Revista Ciência Agronômica, 43, 561-568. https://doi.org/10.1590/S1806-66902012000300020

Robert, G.A., Rajasekar, M., \& Manivannan, P. (2006). Triazole-induced drought stress amelioration on growth yield, and pigments composition of Helianthus annuus L. (sunflower). International Multidisciplinary Research Journal, 5, 6-15.

Souza, F. R., Silva, I. M, Pellin, D. M. P., Bergamin, A. C., \& Silva, R. P. (2015). Características agronômicas do cultivo de girassol consorciado com Brachiaria ruziziensis. Revista Ciência Agronômica, 46, 110-116. https://doi.org/10.1590/S1806-66902015000100013

Tshwenyane, S. O. (2014). Helianthus annuus: A Potential Cut Flower in Botswana, International Journal of Advanced Research in Biological Sciences, 17, 220-223.

\section{Copyrights}

Copyright for this article is retained by the author(s), with first publication rights granted to the journal.

This is an open-access article distributed under the terms and conditions of the Creative Commons Attribution license (http://creativecommons.org/licenses/by/4.0/). 